\title{
PENGEMBANGAN MODUL PEMBELAJARAN MENGGUNAKAN PENDEKATAN PENEMUAN TERBIMBING PADA MATAKULIAH KALKULUS
}

\author{
Alfiani Athma Putri Rosyadi \\ Program Studi Pendidikan Matematika, Universitas Muhammadiyah Malang \\ Alfi_rosyadi@yahoo.com
}

\begin{abstract}
Abstrak
Kalkulus Peubah Banyak merupakan salah satu bagian dari kalkulus yang di dalamnya terdapat pengkaitan antara matakuliah Kalkulus Diferensial dan Kalkulus Integral yang sudah diperoleh oleh mahasiswa pada semester sebelumnya. 80\% mahasiswa tidak bisa menjawab definisi dari turunan dan integral saat dosen membahas pengetahuan prasyarat tersebut. Modul merupakan salah satu alternatif yang dapat ditawarkan untuk mahasiswa karena pembelajarannya bersifat individual. Hal ini diharapkan mahasiswa yang berkemampuan tinggi dan rendah dapat berkolaborasi dengan baik. Penemuan terbimbing yang dapat mengaktifkan mahasiswa dengan langkah-langkah yang sistematis dapat dikolaborasikan dengan modul pembelajaran. Proses pengembangan modul terdiri dari empat tahap. Keempat tahap tersebut adalah tahap pendefinisian (define), tahap perancangan (design), tahap pengembangan (develop), tahap penyebaran (disseminate). Pada tahap Pendefinisian dilakukan analisis pendahuluan yang di dalamnya terdapat pengkajian kurikulum dan materi. Pada tahap perancangan dilakukan dengan menyusun modul sesuai dengan kriteria yang ada pada pendekatan penemuan terbimbing. Selanjutnya pada tahap pengembangan dilakukan validasi oleh tim ahli media dan materi yang dalam hal ini mendapatkan kriteria valid. Pada tahap akhir yaitu tahap penyebaran yang terdapat proses uji coba kepada kelompok kecil dengan hasil valid.
\end{abstract}

Kata Kunci: Modul, Penemuan Terbimbing, Kalkulus

\section{PENDAHULUAN}

Matematika adalah ilmu mengenai konsep-konsep yang saling berhubungan yang terbagi dalam tiga bidang yaitu aljabar, analisis dan geometri. Karena konsepnya saling berhubungan, apabila ada salah satu konsep yang belum dipahami akan melemahkan konsep yang lainnya. Contoh sederhana adalah perkalian yang merupakan penjumlahan berulang, sehingga pada saat menyelesaikan $3 \times 2$ sama dengan menyelesaikan $2+2+2$. Itulah sebabnya kenapa kita perlu memahami konsep penjumlahan dahulu sebelum belajar perkalian. 
Kalkulus merupakan salah satu matakuliah wajib dalam sajian kurikulum jurusan Pendidikan Matematika. Kalkulus Diferensial, Kalkulus lntegral, Kalkulus peubah banyak, dan Fungsi Khusus diberikan pada semester II, III, IV dan V secara berturut turut. Keempat matakuliah kalkulus tersebut mempunyai keterkaitan yang cukup erat. Mahasiswa yang belum menempuh atau tidak lulus kalkulus diferensial, tidak boleh menempuh kalkulus integral dan seterusnya. Hal ini dikarenakan keterkaitan konsep dan materi didalamnya.

Kalkulus Peubah Banyak merupakan salah satu bagian dari kalkulus yang di dalamnya terdapat pengkaitan antara matakuliah Kalkulus Diferensial dan Kalkulus Integral yang sudah diperoleh oleh mahasiswa pada semester sebelumnya. 80\% mahasiswa tidak bisa menjawab definisi dari turunan dan integral saat dosen membahas pengetahuan prasyarat tersebut. Padahal, pada kalkulus peubah banyak tersebut, semesta pembicaraannya diperluas lagi, yaitu untuk fungsi peubah banyak. Apabila mahasiswa mengalami kesulitan dalam memahami materi dasar, maka tentunya akan kesulitan dalam memahami materi yang dibahas. Hal ini yang menjadi salah satu faktor minimnya hasil belajar mahasiwa. Selain terkait dengan kemampuan materi prasyarat, mahasiswa juga mengalami kelemahan dalam kemampuan konseptual.

Kesulitan yang dialami mahasiswa itu ditandai dengan kesalahan yang dilakukan oleh mahasiswa yang mencakup kesalahan konseptual yaitu kesalahan dalam memahami konsep yang melandasi suatu prosedur pemacahan masalah. Berdasarkan pengalaman pada saat pembelajaran di kelas, mahasiswa kesulitan dalam menjelaskan pengertian dari turunan, tetapi mereka secara cepat dapat menyelesaikan turunan dari $f(x)=x^{2}$ adalah $2 x$. Hal ini berarti mahasiswa tidak bisa mengkaitkan pengetahuan yang telah diperolehnya dengan materi yang sedang dibahas.

Pengaitan konsep matematika dengan pengalaman yang diperoleh sebelumnya, dapat menyebabkan mahasiswa tidak mudah lupa terhadap konsep matematika yang ia pelajari. Bahkan ia juga akan lebih mudah mengaplikasikan konsep atau prinsip matematika tersebut, untuk menyelesaikan soal maupun untuk menyelesaikan permasalahan hidup sehari-hari.

Menurut Duane dalam Mbulu (2001:3) menyatakan bahwa tidak ada dua orang yang memiliki tingkat prestasi belajar yang sama, menggunakan cara belajar yang sama, memecahkan masalah dengan cara yang sama dan siap untuk belajar pada waktu yang sama. Pada dasarnya setiap anak mempunyai kemampuan, potensi dan kecepatan belajar yang berbeda. Oleh karena itu diperlukan bahan ajar yang dapat memfasilitasi proses belajar mahasiswa dalam mengembangkan potensi yang ada pada dirinya dengan kecepatan belajar masing-masing. Modul adalah salah satu bahan ajar yang membuka kesempatan bagi mahasiswa untuk belajar menurut kecepatannya masing-masing, menurut caranya masingmasing dan menggunakan tehnik yang berbeda-beda untuk memecahkan masalah tertentu 
berdasarkan latar belakang pengetahuan dan kebiasaaannya masing-masing (Mbulu, 2001: 90)

Modul merupakan suatu kesatuan yang bulat dan lengkap yang terdiri dari serangkaian kegiatan belajar yang secara empiris telah terbukti memberi hasil belajar yang efektif untuk mencapai tujuan yang dirumuskan secara jelas dan spesifik (Mbulu 2001:89). Modul adalah salah satu paket bahan ajar yang disusun secara sistematis dan memuat serangkaian aktivitas belajar mandiri agar mahasiswa mampu mencapai tujuan pembelajaran yang sudah ditetapkan secara khusus dan jelas.

Menurut Ruseffendi (2006: 329) metode (mengajar) penemuan adalah metode mengajar yang mengatur pengajaran sedemikian rupa sehingga anak memperoleh pengetahuan yang sebelumnya belum diketahuinya itu tidak melalui pemberitahuan, sebagian atau seluruhnya ditemukan sendiri. Dengan kata lain pembelajaran dengan metode penemuan merupakan salah satu cara untuk menyampaikan ide/gagasan dengan proses menemukan, dalam proses ini mahasiswa berusaha menemukan konsep dan rumus dan semacamnya dengan bimbingan dosen

Berdasarkan uraian di atas, maka salah satu upaya untuk mengatasi permasalahan tersebut adalah dengan menyusun modul pembelajaran berbasis penemuan terbimbing. Tujuan dari penelitian ini adalah bagaimana proses pengembangan modul dengan pendekatan penemuan terbimbing pada mata kuliah kalkulus.

Modul pada penelitian ini adalah serangkaian kegiatan yang di dalamnya terdapat serangkaian yang sistematis yang di dalamnya terdapat proses pembelajaran untuk mencapai tujuan yang diharapkan. Modul pada penelitian ini dikolaborasikan dengan pendekatan penemuan terbimbing. Hal ini dimaksudkan agar mahasiswa dapat secara efektif melakukan proses pembelajaran.

Ada beberapa hal yang menjadi penciri dari pembelajaran penemuan yaitu: (1) pada kenyataan ilmu-ilmu itu diperoleh melalui penemuan; (2) matematika adalah bahasa yang abstrak; konsep dan lain-lainnya itu akan melekat bila melalui penemuan dengan jalan memanipulasi dan berpengalaman dengan benda-benda konkret; (3) generalisasi itu penting; melalui penemuan generalisasi yang diperoleh akan mantap; (4) dapat meningkatkan kemampuan memecahkan masalah; (5) setiap anak adalah makhluk kreatif; (6) menemukan sesuatu oleh sendiri dapat menumbuhkan rasa percaya terhadap diri sendiri, dapat meningkatkan motivasi (termasuk motivasi intrinsik), melalui pengkajian lebih lanjut;

pada umumnya bersikap positif terhadap matematika. Modul pembelajaran dengan pendekatan penemuan terbimbing dalam penelitian ini terdiri dari kegiatan-kegiatan yang di dalamnya terdapat proses penemuan sesuai dengan langkah-langkah dalam penemuan terbimbing. 


\section{METODE PENELITIAN}

Penelitian pengembangan ini menggunakan model Thiagarajan yang telah dimodifikasi , terdiri dari empat tahap yang dikenal dengan model 4-D (four D Model). Keempat tahap tersebut adalah tahap pendefinisian (define), tahap perancangan (design), tahap pengembangan (develop), tahap penyebaran (disseminate).

Pada tahap pendefinisan, dilakukan analisis kurikulum, mengkaji materi dan mengkaitkan dengan lingkungan, berikutnya adalah tahap perancangan dimana sudah mulai menyusun modul dengan pendekatan penemuan terbimbing. Setelah modul sudah tersusun langkah berikutnya adalah mengembangkan dimana di dalamnya terdapat tahap menvalidasi dan menelaah modul yang sudah dihasilkan. Langkah terakhir yaitu tahap penyebaran dimana dilakukan uji coba kelompok kecil untuk mengetahui bagaimana keterbacaan dan pemahaman mahasiswa terhadap modul yang sudah disusun.

Subjek penelitian dalam pengembangan modul pembelajaran ini adalah dua orang ahli (media dan materi). Sementara uji coba kelompok kecil terdiri dari lima orang mahasiswa yang dengan kemampuan rendah, sedang dan tinggi. Jenis data yang di gunakan dalam penelitian ini adalah data kualitatif dan data kuantitatif. Data kualitatif untuk menganalisis data yang di peroleh dari saran dan komentar. Data kuantitatif di peroleh dari lembar validasi yang di berikan kepada ahli media dan materi.

Instrumen pengumpulan data yang di gunakan dalam penelitian pengembangan ini adalah angket dan wawancara. Angket respon siswa dianalisis secara deskriptif kuantitatif dengan menggunakan skala Guttman. Berikut adalah tabel kelayakan modul setelah divalidasi

Tabel 1. Interpretasi skor kelayakan modul pembelajaran

\begin{tabular}{ll}
\hline Skor & Kriteria Respon \\
\hline $81-100 \%$ & Sangat layak \\
$61-80 \%$ & Layak \\
$41-60 \%$ & Cukup Layak \\
$21-40 \%$ & Tidak layak \\
$0-20 \%$ & Sangat tidak layak \\
\hline
\end{tabular}

\section{PEMBAHASAN}

Berdasarkan hasil validasi ahli media dan materi dapat dilihat pada tabel berikut.

Tabel 2. Persentase kelayakan hasil validasi oleh ahli

\begin{tabular}{llll}
\hline No & Ahli & Persentase & Kriteria \\
\hline 1 & Media & $83 \%$ & Sangat Layak \\
2 & Materi & $85 \%$ & Sangat layak \\
\hline
\end{tabular}


Hal ini menunjukkan bahwa rata-rata dari penilaian tim ahli diperoleh $84 \%$ dengan kategori sangat layak. Selain dari ahli media, data juga diperoleh dari uji coba kelompok kecil yang menunjukkan skor $80 \%$ dengan kategori layak.

Hasil wawancara dengan mahasiswa diperoleh beberapa data yaitu, penyajian modul pembelajaran dapat digunakan untuk matakuliah yang lain agar mahasiswa dapat dengan mudah mempelajari materi di kelas maupun di rumah serta dapat mengerjakan latihan soalnya dengan praktis karena ada kunci jawaban.

\section{PENUTUP}

Proses pengembangann modul terdiri dari empat tahap. Keempat tahap tersebut adalah tahap pendefinisian (define), tahap perancangan (design), tahap pengembangan (develop), tahap penyebaran (disseminate). Pada tahap Pendefinisian dilakukan analisis pendahuluan yang di dalamnya terdapat pengkajian kurikulum dan materi. Pada tahap perancangan dilakukan dengan menyusun modul sesuai dengan kriteria yang ada pada pendekatan penemuan terbimbing. Selanjutnya pada tahap pengembangan dilakukan validasi oleh tim ahli media dan materi yang dalam hal ini mendapatkan kriteria sangat layak. Pada tahap akhir yaitu tahap penyebaran yang terdapat proses uji coba kepada kelompok kecil dengan hasil layak.

Saran untuk peneliti berikutnya adalah modul pembelajaran yang digunakan dapat dikombinasi dengan model pembelajaran lainnya sehingga pelaksanaannya lebih efektif. Penggunaan modul berbasis IT juga dapat digunakan agar mahasiswa lebih terlibat aktif dalam pembelajaran.

\section{DAFTAR RUJUKAN}

Abdul Majid. (2007). Perencanaan Pembelajaran. Bandung: PT Remaja Rosda Karya.

Arief, S. S. Dkk. ( 2006 ). Media pendidikan pengertian, pengembangan, danpemanfaatannya. Jakarta: PT. Raja Grafindo Persada.

Arikunto, Suharsimi. 2010. Prosedur Penelitian Suatu Pendekatan Praktik. Jakarta: PT Rineka Cipta Mbulu, Joseph.2001. Pengajaran Individual. Malang. Yayasan Elang Emas.

Ruseffendi, E. T. (2006). Pengantar kepada Membantu Guru Mengembangkan Kompe tensinya dalam Pengajaran Matematika untuk meningkatkan CBSA. (Edisi revisi). Bandung: Tarsito.

Suherman, Erman dkk. 2003. Strategi Pembelajaran Matematika Kontemporer.Bandung : UPI. 